\title{
芀散染料の水一ベンゼン相間の分配
}

\author{
大阪府亲大学工学部、片山明・黒木宣彦・小西謙三
}

\section{DISTRIBUTION OF DISPERSE DYE BETWEEN WATER AND BENZENE PHASES}

By Akira Katayama Nobuhiko Kuroki and Kenzō Konishi

(Dept. of Applied Chemistry, College of Engineering, University of Osaka

Prefecture, Osaka, Japan)

Isotherms were measured for the distribution of dioxyethylaminoazobenzene (as a model of disperse dye) between water and benzene in the presence and absence of urea or sodium chloride at $10^{\circ}, 20^{\circ}$ and $30^{\circ} \mathrm{C}$. From the results the thermodynamic parameters were calculated for the following process which consists of the transfer of one mole of the dye from a water environment to a benzene one.

Dye in water (mole fraction $X_{W}$ ) $\longrightarrow$ dye in benzene (mole fraction $X_{B}$ )

The changes in the enthalpy and in the unitary free energy and entropy were zero, $-3280 \mathrm{cal}$. $\left(20^{\circ} \mathrm{C}\right)$ and +11 e. $\mathrm{u}_{*}$ respectively. It is seen that the process is nearly athermal and accompanied by a considerably large increase in the entropy. It is therefore clear that the affinity of the dye for benzene (negative unitary free energy change for the process (A)) is not caused by an energetic situation. It is associated entirely with a positive unitary entropy change.

The positive unitary entropy change for the process (A) strongly indicates the formation of so. called "iceberg" water structure in the vicinity of the dye molecule in a water environment. The concept of "iceberg formation" can offer account for the origin of the positive unitary entropy change. When the dye leaves a water environment and enters a benzene one, the "iceberg" around the dye molecule will melt. For this "melt"of "iceberg" again in entropy may be expected.

The approximate number of water nolecules in the "iceberg" around the dye estimated from the thermodynamic parameters was 20 .

The thermodynamic parameters for the process (B) were culculated also.

Dye in water (mole fraction $X_{W}$ ) $\rightarrow$ dye in urea or sodium chloride solution (mole fraction $X_{\text {S01 }}$ )

The unitary free energy change in the transfer of the dye from a pnre water to the 5 mole urea aqueous solution was $-840 \mathrm{cal}$. The negative unitary free energy change indicates that the urea acts to stabilize the dye molecule in an aqueous environment It has been said that the urea breaks the "iceberg", perhaps by some favourable interaction with the "iceberg" regions or by formation of structures similar to urea-hydrocarbon clathrates. According to this hypothesis the transfer of the dye molecule to the urea solution may be caused by an entropic situation.

The unitary free energy change corresponding to the transfer of the dye to the 1 mole sodium chloride aqueous solution was $+480 \mathrm{cal}$. The positive unitary free energy change indicates that the salt acts to unstabilize the dye molecule in an aqueous environment. Kauzmann's assumption that the salt has an effect in promoting the "iceberg formation" can be used to account for this result. The low affinity of the dye for the salt solution may be caused by a large entropy loss resulting from an increase in the extent of the "iceberg" around the dye molecule in the salt solution.

From the results of this study it is reasonable to assume the "iceberg formation" in the vicinity 
of disperse dyes in a water environment, and there is a possibility that the "hydrophobic bond" may play some imprortant role in the interaction between disperse dyes and hydrophobic fibre.

(Received September 27, 1963)

\section{1. 緒言}

著者ら は，先に分散染料とポリプロビレン間の相互 作用を熱力学的に取り报い，得られた熱力学的パラメー タの值から両者の間にはエントロピー的な結合力である “hydrophobic bond” の存在する可能性のあること示

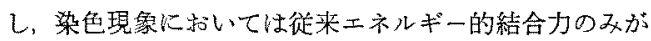

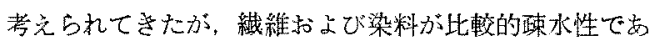
る場合には瀻雓一染料間の結合力としてェントロピー的 結合力学考慮すべき必要があるものと考觉た。

本報では，この問題をさらに基礎的に検討するため， 分散染料の水一ベンゼン相間の分配の熱力学的取り报い 盐行ない，得られる熱力学的パラメ一タの值から，水溶 液中に路いて分散染料周辺には果し， 亿“hydrophobic bond”生成のために㤬不可欠でする“iceberg”が形成さ れているか否か，また形成されているものと文ればどの 程度の大きさの“iceberg”が存在古るが推定し，さら に染色現象に皮いて “hydrophobic bond”が瀻維一染 料間の結合にとの程度の筑与をなしらるかる娭討した。

\section{2. 試料および実験方法}

試料 染料惊合成品を水アルコール（1：1）溶液か ら数回再結晶して精製し, 純品と思われるるのを使用し た。染粦の構造沶よひ性質を第1表に示した。

用いた染料恃分散染料としては水に刘する溶解度のか なり大きなるのであるが，これは水拈よびベンゼン相中 の染料澧度の測定が容易であることを考虑して選んだも ので市る。著者らが行なつた実騷範囲内では用いる染料 がジオキシェチルアミノアゾベンゼンよりる親水性であ ればベンゼン相中の，また踈水性であれば水相中の染料

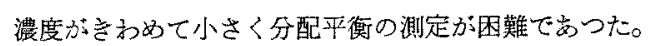

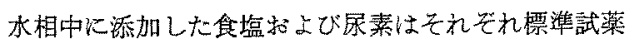
抢よび試薬特級品をそのまままだンゼンは蒸留精製 したものを用いた。

実験方法 蒸留水 $10 \mathrm{~m} l$ K種種な染料溍度のベンゼン 溶液 $10 \mathrm{~m} l$ そ加之, 恒温槽中に所定温度に8時間ときど
き手で激しくふりまぜなぶら放置し，水，ベンゼン雨相 が完全に分離した後，雨相から一定量をピペットアウト

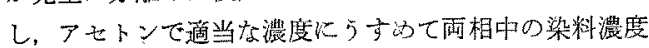
を比它定量した。な和，熱力学的取り扱いを可能と一る

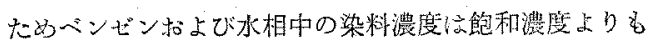
かなり低くなるように実験条件を選えた。

\section{3. 結果および考察}

\section{i) 分散染料の水ベンゼン相間の分配}

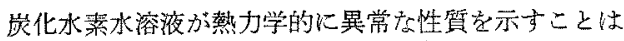

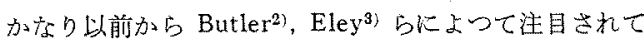
いたが，Frank，Evans ${ }^{4}$ は宸化水素周辺の水分子は通 常の水の構造に比へて規則性の高い“iceberg”を形成 しているものとしてその異常性の説明を試みている。

染料分子とくに分散染料の上5な蹯水性の染料儿おい ては分子中にかなりの炭化水素部分が存在し，またスル ホン酸基，カルボキシ基の上らな極端な親水性基は存在 しないのて，承溶液中に招いてをの周辺に“iceberg”が 形成されている可能性は大きい。

染料分子周讱に“iceberg” の形成を若えることが妥当 であるか否がしるため，本報ではるす分敬染料の水一 ベンゼン相間の分配を調へ，つぎの5な過程(1)，主 なわり染料分子 1 モルが水相中からベンゼン相中に䔟行 t

水中の染料（モル分率 $X_{W}$ )

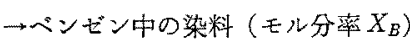

る際の蓺力学的パラメータの值艺計算した。

分配定数を $K=X_{B} / X_{W}$ とすれば，移行に際しての自 由エネルギー変化，エンタルピー恋化䇛よびエントロピ 一変化はそれをれ次式で表わされる。

$$
\begin{gathered}
-\Delta F_{u}=-R T \ln K \\
-\Delta H=d[R \ln K] / d[1 / T] \\
\Delta S_{u}=[1 / T]\left(\Delta H-\Delta F_{u}\right)
\end{gathered}
$$

ここで, $\Delta F_{u}, \Delta S_{u}$ などに付した添字 は自由エネル ギー和よびエントロピー変化が組成項を含まない固有項 (unitary term) のみの变化に対広るること少示す。

Table I

\begin{tabular}{c|c|c|c|c|c|c}
\hline chemical formula & $\mathrm{mp}\left({ }^{\circ} \mathrm{C}\right)$ & \multicolumn{2}{|c|}{$\mathrm{N} \%$} & \multicolumn{3}{|c|}{ solubility $(\mathrm{mg} / \mathrm{l})$} \\
\hline & $\mathrm{N}-\mathrm{N}=\mathrm{N}-\left\langle\left(\mathrm{C}_{2} \mathrm{H}_{4} \mathrm{OH}\right)_{2}\right.$ & 132 & found : 14.9 & $0^{\circ}$ & $25^{\circ}$ & $90^{\circ}$ \\
\hline & & calcu : 14.7 & 86.7 & 124 & 830 \\
\hline
\end{tabular}




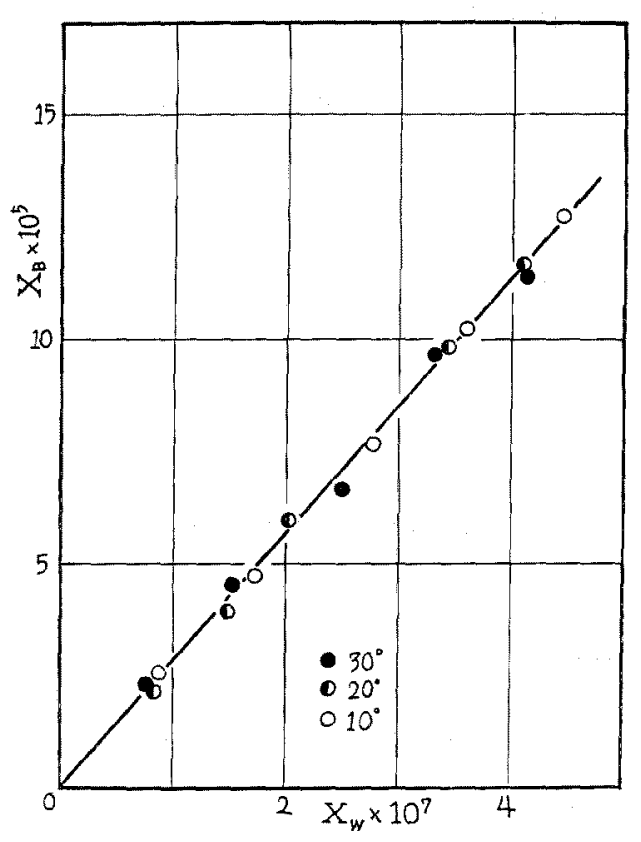

Fig. 1. Distribution of dioxyethylaminoazobenzene between water and benzene at $10^{\circ}, 20^{\circ}$ and $30{ }^{\circ} \mathrm{C}$.

Table II

Thermodynamic parameters for process (1)

\begin{tabular}{|c|c|c|c|c|}
\hline \multicolumn{3}{|c|}{$\Delta F_{u}(\mathrm{cal})$} & $\Delta H$ & $\Delta S_{u}(\mathrm{eu})$ \\
\hline $10^{\circ}$ & $20^{\circ}$ & $30^{\circ}$ & \multirow[b]{2}{*}{0} & \multirow{2}{*}{+11} \\
\hline-3170 & -3280 & -3390 & & \\
\hline
\end{tabular}

$10^{\circ} ， 20^{\circ}$ 扣よで $30^{\circ} \mathrm{C}$ 厄赫いて測定した分配平衡の結 果定第1図に，また(2)，(3)执よず(4)式を用いて計 算した熱力学的パラメータの值を第 2 表に示した。

第 2 表より明らかなように分散染料の水相中からベン ゼン相中への移行に際しては自由エネルギーの減少を伴 ない，染料分子使相からのがれてベンゼン相中へ移行 しょうとする傾问を有する。しかて，この際エンタルピ 一変化はゼロまたまたはをれに近い值であり，過程(1) はにとんど無熱的であるので, 移行傾向はすべてニント Fピー変化が正であることに由来するすのであり，染料 分子が水相中からベンゼン相中に移行することに上つて 系のェントロピー憎大する。

この带寒は，办溶液中心おいて染制分子周过火“iceberg”が形成されているとする考光方の妥当であること を支持し，水相中儿打いて染料分子周辺に形成さ礼てい た “iceberg”は染料分子がベンゼン相中に䔟行すること によつて崩壊しより秩序性の少ない通常の水の棈造に
もどるため系のエントロビーが堌大するる。と考克られ 可。

Scheraga ${ }^{5)}$ に上れば, “iceberg” の形成には炭化水素 部分をとりまく水分子の蛙で第一層中心存在する多のの みが関与するすのとしているが，つぎにジオキシエチル アミノアゾペンゼンによつて形成される “iceberg” 中に 何分子程萑の水分子が存在するがこく大ざつ代考克 てみる。

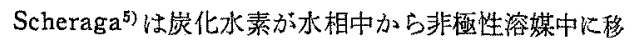
行する際の自由エネルギー変化は次式で変わされるもの としている。

$$
\Delta F_{\text {q }}=Y^{S}\left[F_{W}{ }^{0}-F_{W} C-(1 / 2) E_{R W}\right]+Z_{R} E_{R}+\Delta F_{\text {rot }}
$$

ここで，Ys $Y^{s}$ “iceberg” 中の水分子の数， $F_{W}{ }^{0}, F_{W}{ }^{c}$ は通常水却よび“iceberg” 中の水の部分モル自由エネル ギー， $E_{R W}$ 注水一㞸化水素間の相互作用のエネルギー, $Z_{R} E_{R}$ は掞化水素一非極性溶媒間の相互作用のエネルギ 一, $\Delta F_{\text {rot }}$ 惊闭相中に和ける炭素一炭素結合閻の䢙転の 自由度の差火基つく自由泣ルギー変化である。

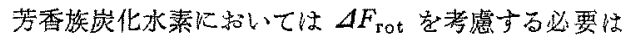

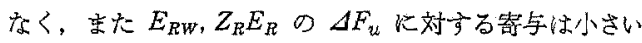
ので5), 近似的に $\Delta F_{U} \div Y^{S}\left[F_{W}{ }^{0}-F_{W}{ }^{c}\right]=Y^{S}$. const $z$ 考充られ移行の百由工ネルギー変化方大体等しい笮化水 素類に执いてはYS の值にも大差ないものと考学ること ができる。

ベンゼンはとの “iceberg”中に約 20 個の水分子を有

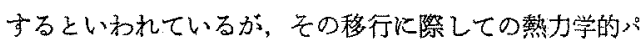
ラメータとしては $\Delta F_{u\left(10^{\circ}\right)}=-4070, \Delta H=0, \Delta S=+$ 14 という值が得られている5 。これらの值はジオキシ サルアミノアゾベンゼンのそれと大体等しく, 徒つてこ の染料周䢞の “iceberg” 中に約 20 . 個程度の水分子が 存在しているすのと推定される。

(5)式炭化水索類について得られたものであつて, 染料分子のよ5に極性基劣有する多のについてはそれら 関する考慮が必要であるが，ごく大ざつばに論議する 上には(5)式を用いて本報の結果を論じてる特別の支障 はないタのと考去られる。

\section{ii）水相中への尿素および食塩添加の影響}

本節では，水相中への尿素佶さび食塩を添加しだ場 合，分配平衡がどのよ5に变化するが調べた。

尿素特よび食塩を添加した場合の分配平衡の結果艺と れぞれ第 2 罒㕲よび第 3 図に示した。

ここで，次のような過程を考兄

純水中の染料 一尿素(食㙏)水溶液中の染料 (6) この上らな過程にともなら熱力学的パラメータの值を前 節括上び本節の結果を用いて計算してみる。 


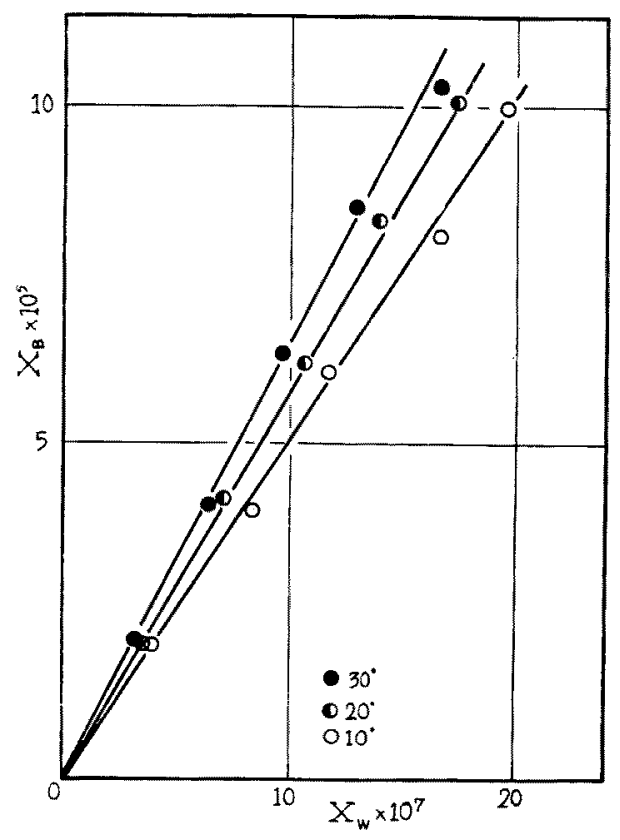

Fig. 12. Distribution of dioxyethylaminoazobenzene between 5 mole urea aqueous solution and benzene at $10^{\circ}, 20^{\circ}$ and $30^{\circ} \mathrm{C}$.

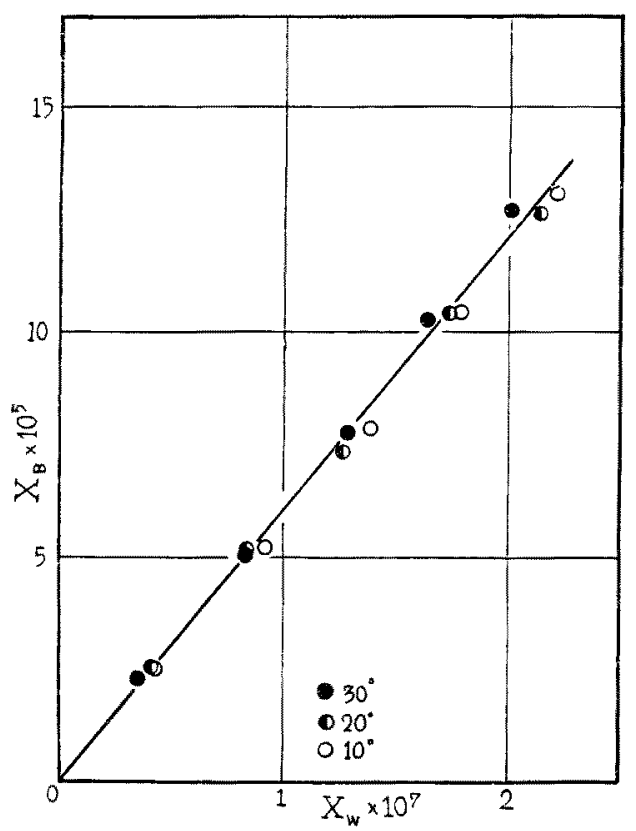

Fig. 3. Distribution of dioxyethylaminoazobenzene between 1 mole sodium chloride aqueous solution and benzene at $10^{\circ}, 20^{\circ}$ and $30^{\circ} \mathrm{C}$.

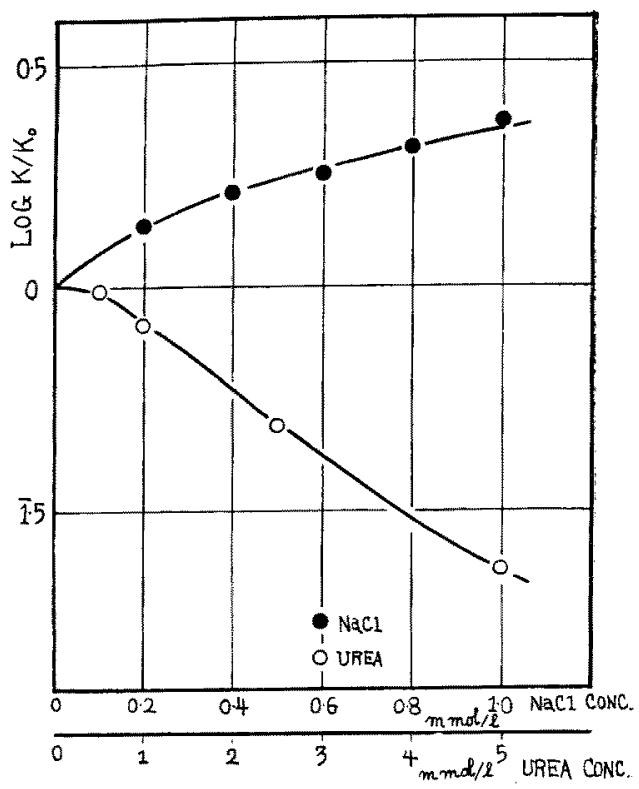

Fig. 4. Relation between $\log K / K_{0}$ and urea or sodium chloride concentration at $20^{\circ} \mathrm{C}$.

Table III

unitary free energy changes for process ( 6 )

\begin{tabular}{ll|c|c|c|c}
\hline urea conc. (mmol/l) & 0.5 & 1.0 & 2.5 & 5.0 \\
\hline$A F_{t r}\left(20^{\circ}\right)$ (cal) & -20 & -110 & -420 & -840 \\
\hline
\end{tabular}

Table IV

unitary free energy changes for process (6)

\begin{tabular}{c|c|c|c|c|c}
$\mathrm{NaCl}$ conc. \\
(mmoll) & 0.2 & 0.4 & 0.6 & 0.8 & 1.0 \\
\hline$A F_{t r\left(20^{\circ}\right)}$ (cal) & +190 & +280 & +340 & +420 & +480 \\
\hline
\end{tabular}

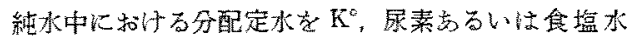

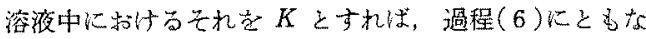

5 自由工ネルギー変化は次式で表わされる。

$$
\Delta F_{t r}=-R T \ln K^{\circ} / K=\Delta F_{u}-\Delta F_{u \cdot s 01}
$$

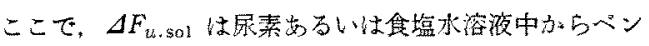
ビン相中へ染料分子が移行る察の自由工ネルギー変化 宗示。

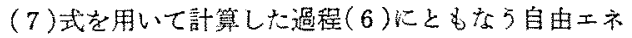

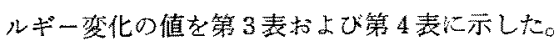

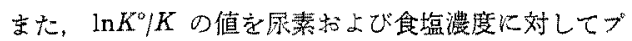
ロットした結果を第 4 図に示した。

第 3，4表和上び第 4 因上り明らかなよ 3 亿，純水中

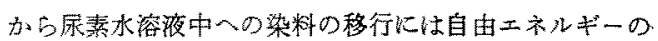
減少をと立ない，純水中加ら食塩水溶液中への天れには 
自由エネルギーの徣加をとなう。

このような相反する移行にともなら自由エネルギー変 北は，染料分子周辺の“iceberg”の形成を仮定すること によつて矛盾なく説明することが可能でらる。

まず，尿素は水溶液の哜電率をが就り変化させるが,

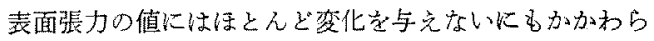
ず，炭化水素の水に対する溶解度岩增加し，たん自質の 変性をうながしを界面活性物犋のミれル臨界湄度を增 大させるなどの作用の岕ることはよくしられている。

近年，これらの作用は展素が“iceberg”を崩填させる ことに基づくものとする説 ${ }^{5,6,7,8)}$ が有力であり，去の機 搆については未だ明らかでないが，1）炭化水素周辺に 形成されている“iceberg”中の水分子に尿素方骤先的に

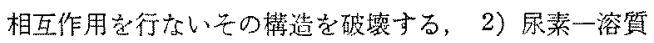
間にクラスレイト樣の構造が生成する8 ている。

尿素にこのような“iceberg”を崩壊させる作用がむる とすれば，层柡水溶液中心さいて染料分子周辺に形成さ れている“iceberg” の大きさは純水中のそれに比べて小 さく，従つて染料分子は純水中に和けるよりあ辰素水溶 液中に持ける万がエントロビー的により安定となり，染 料分子は水溶液中から䐂素水溶液中八と移行㑯向圭有与 るようになるものと解される。

また，第 2 図の尿素水溶液一ベンゼン相間の分配平衡 の結果は，水一ベンゼン，食塩水溶液一ベンゼン間の分 配の場合之異なり，分配定数 $K$ の值は温度の上界とと もに大となり見掛上エンタルピー変化は正の值をとるよ 5に欢えるしかし，“iceberg”の一部が崩壊してェン タルと゚ー変化が正となることは理解し難く, むしろ温度 飞よつて尿素—“iceberg”間の相互作用力に美異が生ず るためではないかと考光られるが、なお今後の検討を要 する。

一方，食塩が “iceberg” の形成を助長する作用の荡る ことは Kauzmann ${ }^{6)}$ によつて指摘されて和り，このこ とを考留すれば，染料分子は食塩水溶液中に㧅いて純水 中に持けるよりもエントロピー的に上り不安定となり， そのた的染料分子は食塭水溶液中から純水中八の秋行傾 向を有するるのと解することがでさる。

つぎK, Scheraga5) の考方方に従つて式の誘樽を行 なつてみっと染料分子が純水中から尿素あるいは食程水 溶液中へ移行するときの自由エネルギー変化は次式で表 わされるはずである。

$$
\Delta F_{t r}=\Delta Y_{S}\left[F_{W^{0}}-F_{W}{ }^{C}-(1 / 2) E_{R W}\right]
$$

たたし， $\Delta F_{\text {rot }}$ 純水，尿素あるいは䫀塩水溶液中心 挌いて変化しないものと考党る。

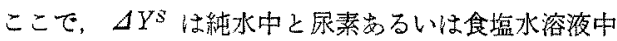

に括いて形成される “iceberg” の中に存在小る办分子数 の差を洨わす。

前節と同様， $\Delta F_{t \tau} \fallingdotseq \Delta Y^{S}\left[F_{W}{ }^{0}-F_{W}{ }^{C}\right]$ と孝えると 5 モル尿素水溶液中に扣いては純水中に打江る “iceberg” の1/4すなわら 5 分子程度の水分子が崩塔し， 1 モル食 塩水溶液中に和いては“iceberg”中の水分子は $2 \sim 3$ 分 子程度增加しているものと推定される。

前節で述べたよ5に染料分子帆に存在する極性基の “iceberg”形成に対する笴与が明らかでないので，詳細 は今後の颂討にゆずる。

\section{iii) 染色現象と "hydrophobic bond"}

前節までに得られた結果からみて，水溶液中に坮いて 染䊀分子周辺には“iceberg”が形成されているものと考 兊てまず間違いはないであるう。

本瓣では，分配平衡の測定を容易とするため炭化术素 部分の小さな染料を選んだが，実際染色に用いられるよ ろなさらに炭化水素部分の大きならり瑓水性の染料に拉 いては形成される“iceberg”の大きさもさらに大とな

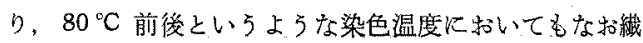
維一染料間には “hydrophobic bond” の㘯らく可能性が 存在するものと考えられる。

例えば，分子中に長鎖アルキル基を有するカルボラン 染料が羊毛に対して高い親和力を示し，またアルキル鎖 を有する分散染料は，同程度の親水性を有する芳香環の みからなる染料に比べてポりプロピレンをよく染色す る9)ことなどがしられているが，アルキル鎖はチェイン エントロピーの奇与地范つて芳香族炭化水素類に比心゙ て “hydrophobic bond” 形成能の大きな基であるので, 分子中にアルキル基を樽入することによる親和力の增大 は分散力などに基つくエネルギー的結台力の第与による とするよりももしろエントロピー的結合力である“hyd rophobic bond”の寄与に上る车のと考完る方が妥当で はあるまいか。

ただ，通常染色はかなり高温で行なわれ，また可溶性 高分子の場合と異なり，瀻維（䠅水性）を基質として選 ふ心場合には㵶維高分子鎖をとりまく水分子小数はきわ て少なく，㵶維高分子鎖岩化水菜部分䦌辺に形成される “iceberg”も小さくなり往つて䋐維一染料閶 “hydrophobic bond” 主として染料分子の等与のみによつて起 るものと考党られ，染色現象に晾いては可溶性高分子一

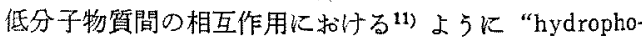
bic bond”が相互作用の主役を演ずるとい5ならな可能 性は少ない。

可溶性高分子一低分子物質間の相互作用に执いては正 のエンタルピー変化が報告されているにるかかからず， 染色現象に括いては分散染料一ポリプロピレン采に乱い 


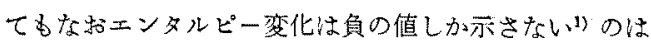
このような理由によるものと思われる。

染色現象に拈いては，分散力などに基つくエネルギー 的相互作用が大きな需与をしていることは確加でする が，染色現象正しく理解するためには “hydrophobic

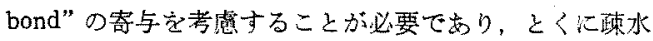

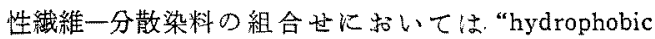
bond”林䄉維一染料間の相互作用に対して重要な役割 を演ずる可能性があるであるう。

\section{5. 総 括}

分散染料の水一ベンゼン相間の分配の熱力学的取り扱 いを行なつた結果つぎのことを明らかにした。

1) ジオキシニチルアミノアゾベンゼンの承相からべ ソゼン相への移厅は倞とんど門熱的に行なわれ，移行に 際してエントロピーは增大し，このエントロピー增加が 移行の原因で京る。

2) 水相中に尿素添加すれ你染料分子の安定性を堌 し，食塩を添加すればより不安定となる。

以上の結果穵，水溶液中に招いて染料分子周辺に“ic eberg”が形成されているものと考克て説明し，胨俈現 象に括ける “hydrophobic bond”の然与について教慗を 行なつた。

本研究の一部は昭和 38 年度瀻襍学会「染色化学討諭 含」（東京）に括いて発表したすのである。

\section{文献}

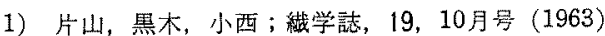

2) Butler; Trans Faraday Soc., 33, 229 (1937)

3) Eley ; ibid. 35, 1281, 1421 (1939)

4) Frank, Evans ; J.Chem. Phys., 13, 507 (1945)

5) Scheraga ; J. Chem. Phys., 36, 3382, 3401 (1962)

J.Phys. Chem., 66, 1773 (1962)

6) Kauzmann ; Advances in Protein Chem., 14, 1 (1959)

7) Burning, Holtzer; J. Am. Chem. Soc., 83, 4865 (1961)

8) Mukerjee, Ray ; J.Phys. Chem., 67, 190(1963)

9) 吉武, 檑本; 染色工業，9，423 (1961)

10) Aranow, Witten; J. Phys. Chem., 64, 1643 (1960)

11) Molyneux, Frank; J. Am. Chem. Soc., 83. 3169 (1961) 